\title{
I Barbari e I'Italia. Un problema de honestidad editorial
}

\author{
GISELA RIPOLL LOPEZ
}

La publicación del libro de M. Sordi, R. Barbieri, H. Steuer, G. Ripoll, S. Chierici, M. Giudetti, G. Penco y C. Wickham, I barbari e I'Italia, editado por Fratelli Melita Editori en su colección "l segni della cultura" (1992), constituye ante todo un grave y flagrante caso de falta de honestidad, de honestidad editorial.

Determinados sectores del mundo editorial, con patente de corso, han cedido a la tentación de reconvertir el sector en un mar poblado de piratas, recordando al histórico Barbarroja o al novelesco y tantas veces soñado capitán Garfio. No por esta razón creemos fue elegido el nombre de aquella nereida llamada Melita que vivia en el fondo del mar. Precisamente esta publicación de los Fratelli Melita sobre I Barbari e ritalia constituye un ejemplo claro de este piraticam facere editorial, cuyas obras se fabrican y componen - sin previo aviso a los autorescon el único objetivo de venderlas directamente en las librerías de saldo. Compuesta por el sistema de yuxtaponer varios capítulos de diferentes autores y con el fin de exponer la problemática de la presencia de los pueblos bárbaros en Italia, podría haber sido una laudable iniciativa sobre un episodio histórico que efectivamente requiere una obra de conjunto, realizada por historiadores, filólogos y arqueólogos. Sin embargo, el resultado obtenido por los Fratelli Melita es desgraciadamente poco recomendable y abusivamente falto de honestidad. Insisto en ello porque el libro es un "collage" construido con fragmentos fruto de un despiadado recorte de otros libros, libros que en su origen tenían una coherencia y habían sido elaborados con un objetivo concreto. Cada una de las obras originales tenía una homogeneidad y perseguía unos fines concretos, basados esencialmente en dar a conocer al gran público una serie de investigaciones científicas en curso y básicamente con una reflexión de carácter más divulgativo.

No haré alusión a los textos de los otros colegas que colaboran en el libro de I barbari e I'Italia, a los que también se ha violentado en su 
obra y cuya fuente esencial es la Jaca Book. Sin embargo, sí quiero detenerme en ciertos aspectos que me conciemen directamente. El libro lleva incorporadas una serie de ilustraciones correspondientes a monumentos, yacimientos y materiales visigodos de la geografía hispánica, que habian sido realizadas por Isabel Valls. Resulta inverosimil que en un libro que trata sobre Italia aparezcan estas ilustraciones, y que, aunque magníficas, nada tienen que ver con Italia y Teodorico. Quizá sea tan sólo una cuestión de lucro. La tercera parte de dicho libro está compuesta de los capítulos "Origini e migrazioni del popolo goto" (págs. 136-144) y "Gli Ostrogoti in Italia" (págs. 161-180). Estos textos formaban parte del libro llamado / Goti, firmado por Pedro de Palol y Gisela Ripoll, y publicado por la editorial Jaca Book en 1989, aunque la edición original, con el título Los godos en el occidente europeo. Ostrogodos y visigodos en los siglos $v$-vIII es de 1988 y fue realizada en Madrid por Ediciones Encuentro. En un principio esta obra pretendía ser únicamente una introducción a la peregrinatio gothica para un gran público esencialmente hispánico. Así lo deciamos en nuestra introducción y éramos conscientes del problema. El libro de I Goti, traducido - mal traducido, recortado y no supervisado- habia sido escrito, en su versión original castellana, en colaboración con Pedro de Palol, Catedrático Emérito de la Universidad de Barcelona, y maestro de profesionales, investigadores y profesores universitarios a lo largo de muchas generaciones. Sorprendentemente en la publicación de los Fratteli Melita, parece que ha habido una dudosa voluntad optando finalmente por la damnatio memoriae del Profesor Palol, dejando a un único autor como responsable de dicho texto. No se trata de hacer aqui una justificación, pero creo necesario hacer algunas aclaraciones sobre los capítulos reproducidos, que aunque corresponderían más a una recensión del propio libro, creo que éste es el lugar más oportuno.

Si alguien en alguna ocasión me hubiese pedido reproducir el capítulo "Orígenes y migraciones del pueblo godo", le hubiese contestado con un rotundo "no". Se trataba de un capítulo cuya elaboración habia sido muy penosa dada la falta de nueva bibliografía a la que tuvimos acceso -aunque sabíamos de nuevas excavaciones y muy parciales publicaciones- en el momento de redactar el texto original del libro de Los godos en el occidente europeo (publicado en 1988, pero escrito en 1984). ¿Cabe por tanto hablar de mea culpa? Quizás sí en la primera edición, pues éramos conscientes con el Profesor Palol que escribir, sin haber podido reflexionar sobre las novedades, era arriesgado, pero no en la segunda edición así presentada por Fratelli Melita Editori. Por aquel entonces se había oído todavía hablar muy poco - al menos entre los visigotistas hispánicos- de las culturas de Wielbark, Cernjachov, Sîntana- 
de-Mures, etc. Actualmente ya se pueden empezar a realizar con más facilidad síntesis incluyéndose las muy recientes novedades. Tal es el caso de la exposición y catálogo de / Goti de Milán (V. Bierbrauer, $O$ von Hessen y E. Arslan, edits., I Goti, Electa, Milán, 1994; véanse particularmente los primeros capítulos de dicho catálogo y en especial el de $\mathrm{V}$. Bierbrauer, que hace referencia al inicio de la migración).

El capítulo dedicado a los ostrogodos en Italia y especialmente al reinado de Teodorico, pretendía ser una introducción general, es decir acercar a un público en general a la historia y cultura italianas de ese periodo, intentando plantear determinada conexiones que existen entre el reino de Teodorico en Italia y el regnum visigothorum de Hispania. A nivel histórico el ejercicio e imagen del poder tanto en el reino ostrogodo como en el reino visigodo, mantiene estrechas conexiones. Por otra parte, la presencia de Teodorico en Hispania como tutor de su nieto Amalarico, lo que conocemos como «intermedio ostrogodo", es muy sugerente para los investigadores hispánicos en su intento de analizar y comprender determinados fenómenos políticos, culturales y artísticos. Respecto a este último aspecto, la arqueología ha puesto de manifiesto un gran número de materiales funerarios que recalcan precisamente las estrechas conexiones existentes entre los materiales aparecidos en los territorios de los dos reinos. Incluso actualmente algunos investigadores creen que los objetos de adorno personal aparecidos en las necrópolis de la Meseta Castellana tienen una directa filiación con la presencia de tropas militares ostrogodas y no con su origen aquitano (P. PÉRIN, "L'armée de Vidimer et la question des depôts funéraires chez les Wisigoths en Gaule et en Espagne (Ve-Vle siècles)", L'armée romaine et les barbares du IIle au VIle siècle, Association Française d'Archéologie Mérovingienne, Mémoires V, Rouen, 1993, págs. 411-423). Creo que es evidente que en ningún momento pretendimos los autores dar una lección a nuestros colegas, particularmente italianos, sobre Teodorico y los restos arquitectónicos y arqueológicos que su reinado nos ha dejado. Las recientes publicaciones aparecidas en ocasión a la conmemoración teodoriciana de 1992 (Teodorico il Grande e i Goti d'Italia, Atti del XIII Congresso internazionale di studi sull'Alto Medioevo, 1992, Spoleto, 1993), muestran que ese capítulo no se debía haber publicado por Fratelli Melita Editori, sin antes ofrecer la posibilidad a los autores de incorporar en él todas las novedades de los últimos años y las reflexiones oportunas al respecto. Inicialmente, en el libro de Los godos, el capítulo tenía una coherencia - al menos eso pretendíamos- dentro de todo el volumen y ahora éste ha quedado completamente desgajado.

En muchos casos, profesores universitarios, investigadores y profesionales dedicados a la historia y a la arqueología creemos que es nece- 
sario elaborar un libro de divulgación, de lectura fácil y fluida, ilustrado con abundantes mapas, dibujos y fotografías a color y blanco y negro, pero toda esa motivación desaparece cuando se practican procedimientos como el de Fratelli Melita Editori y su I barbari e I'/talia. Es por ello que, desde estas líneas, deseo expresar mi más profunda insatisfacción y total desacuerdo frente a la deshonesta forma de actuar de dichos editores. 